\title{
Stage IVA Thyroid Gland Medullary Carcinoma AJCC v8
}

National Cancer Institute

\section{Source}

National Cancer Institute. Stage IVA Thyroid Gland Medullary Carcinoma A/CC v8. NCI

Thesaurus. Code C141047.

Stage IVA includes: ( $\mathrm{T} 4 \mathrm{a}$, Any $\mathrm{N}, \mathrm{M} 0)$; ( $\mathrm{T} 1-3, \mathrm{~N} 1 \mathrm{~b}, \mathrm{M} 0)$. T1: Tumor measuring $2 \mathrm{~cm}$ or less in greatest dimension limited to the thyroid. T2: Tumor measuring more than $2 \mathrm{~cm}$ but less than $4 \mathrm{~cm}$ in greatest dimension limited to the thyroid. T3: Tumor measuring 4 $\mathrm{cm}$ or more in greatest dimension or with extrathyroidal extension. T4a: Moderately advanced disease; tumor of any size with gross extrathyroidal extension into the nearby tissues of the neck, including subcutaneous soft tissue, larynx, trachea, esophagus, or recurrent laryngeal nerve. N1b: Metastasis to unilateral, bilateral, or contralateral lateral neck lymph nodes levels I, II, III, IV, or V or retropharyngeal lymph nodes. M0: No distant metastasis. (from AJCC 8th Ed.) 